doi:10.18575/msrs.sm.e.16.25

UDK 616.342-002-02:618.5

COBISS.RS-ID 6165528

\section{Acute Pancreatitis in Pregnancy}

\begin{abstract}
Introduction: Acute pancreatitis in pregnancy is usually diagnosed in the third trimester. The most common etiology factors are cholelithiasa and choledocholithiasa. The most severe consequence is perinatal and maternal mortality. The lethal outcome is largely reduced due to the widespread use of the following: contemporary diagnostics (ultrasound, magnetic resonance imaging, endoscopy and laparoscopy) and multidisciplinary approach to problem solving.
\end{abstract}

Key words: acute pancreatitis, pregnancy

(Scr Med 2016:47:153-155)

\section{Milana Stanić, ${ }^{1}$ Dejan Nikić, ${ }^{1}$ Vera Gazić ${ }^{1}$}

${ }^{1}$ Department of Anesthesia, University Clinical Center of the Republic of Srpska, Banja Luka

Contact address:

Milana Stanić

Sime Miljuša $28 b$

7800 o Banja Luka, Republic of Srpska

Bosnia and Herzegovina

E-mail: smilica@teol.net

Telephone: +38765671674

Submitted: May $11^{\text {th }}, 2016$

Accepted: May 26 $6^{\text {th }}, 2016$

\section{Introduction}

Acute pancreatitis in pregnancy is not an uncommon problem. Annual incidence is from 5 to 80 per 100.000 citizens. However, during pregnancy it varies and ranges from 1 in 1.000 to 1 in 10.000 pregnant women. ${ }^{1-3}$ More than $50 \%$ of cases are diagnosed in the third trimester of pregnancy. The most common cause of acute pancreatitis in pregnancy is gallstones. ${ }^{1}$

\section{Case report}

A pregnant woman in the 34th/35th week of pregnancy, age 33, was hospitalized at the Clinic of Gynecology and Obstetrics in Banja Luka on the 6th of September 2015 due to the abdominal pain. Aware, afebrile, subicteric, $\mathrm{TA}=110 / 80 \mathrm{mmHg}, \mathrm{f}=12 \mathrm{O} / \mathrm{min}$., pale. She normally felt fetus movements. Obstetric result: Gestational age 34|35 NG, PVU disappeared, dilation 3-4 cm, edges of medium thickness, medium elastic, fetal membranes whole, the head of the fetus in the forefront, loosely fixed above the pelvic inlet, did not feel contractions, FSF (+) positive, CTG attached. Examined by an abdominal surgeon and moved to the Clinic of General and Abdominal Surgery. In the laboratory: pancreatic amylase $=2664 \mathrm{U} / \mathrm{L}, \mathrm{Ca}=2.09$ $\mathrm{mmol} / \mathrm{L}$, total bilirubin $=63 \mu \mathrm{mol} / \mathrm{L}$., direct bilirubin $=58.7$, hemoglobin $=88 \mathrm{~g} / \mathrm{L}$. Ultrasonically, distinctly distended gallbladder, wall thickened with visible intraluminal calculi and suspected calculi in the cystic duct. (Picture 1.)

Picture 1. The ultrasound findings of the gallbladder with clearly identifiable intraluminal stone

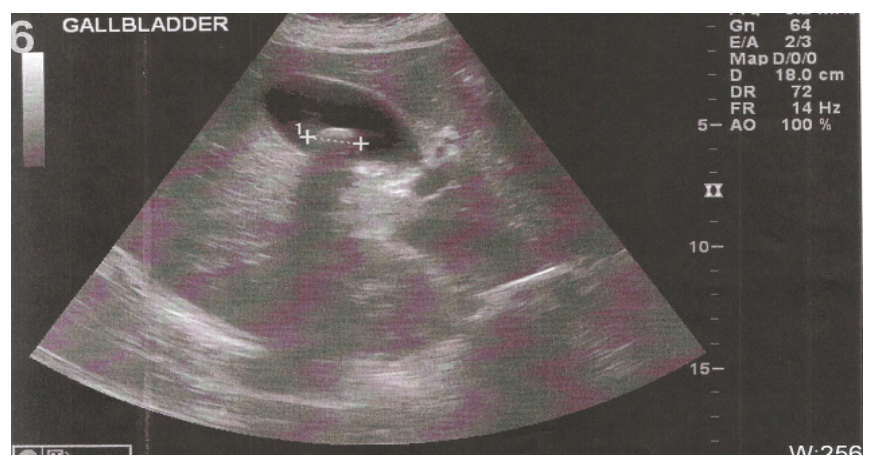

RTG pulmo was clean. On September, 6th 2015, in agreement with the attending gynecologist, a surgical procedure was indicated. In the introduction of anesthesia $\mathrm{TA}=140 / 80 \mathrm{mmHg}, \mathrm{f}=130 / \mathrm{min}$. The patient was introduced into a general endotracheal anesthesia (OEA), according to the protocol for obstetric anesthesia. The patient was intubated and put on controlled mechanical ventilation with a mixture of gases 02 , Nitrogen oxide (N2O) and Sevorane. Relaxation was continued with Tracrium. After laparotomy, Dorfler's variant of the section 
was performed. Live premature male child $2720 \mathrm{~g} / 48 \mathrm{~cm}$ was born, AS 9/9, accompanied by a neonatologist and a midwife and relocated to the Department of Pediatrics. After the childbirth, anesthesia was continued with opioid analgesic, fentanyl in a dose of $400 \mathrm{mcg}(8 \mathrm{ml})$. During OEA, the patient was profusely rehydrated $(4500 \mathrm{ml} 0.9 \%$ $\mathrm{NaCl}$ ), TA around $140 / 85 \mathrm{mmHg}$, ventilation parameters: $\mathrm{VT}=560 \mathrm{ml}$, fr.12 $\mid$ minute, $\mathrm{SpO} 2=100 \%$, diuresis after the end of surgery - 100ml. After the delivery, cholecystectomy was performed. Choledochotomy with $\mathrm{T}$ drainage was done after the dilation of the papilla of Vater. Due to the low hemoglobin, blood products were transfused. Postoperative treatment was continued in JILa (three days, from September, 6th to September, 9th 2015). Upon the reception to the Intense Care Unit: hemodynamicly unstable, hypotensive $(\mathrm{TA}=90 / 65 \mathrm{mmHg})$, tachycardia, fr. $=120 / \mathrm{min}$. During the treatment in intensive care, $13500 \mathrm{ml}$ of crystalloid solution was given, diuresis during 24 hours was on average of $1500 \mathrm{ml}$, respiratory condition was stable, $\mathrm{SpO} 2=97 \%$. Laboratory biochemical findings were as follows: September, 6th 2015: $\mathrm{E}=3.7 \mathrm{HGB}=86$ $\mathrm{HCT}=0.27 \mathrm{~L}=13.3$, Platelets $=29$ and 24 in the repeated report. Amylase in serum=2664, Amylase in urine 234, total bilirubin $=63.7$ Direct bilirubin $=58.3$. Correction of CSF was done, treated with: red blood cell concentrate erythrocytes in a dosage of $330 \mathrm{ml}$, re-suspended erythrocytes in a dosage of $380 \mathrm{oml}$, a $240 \mathrm{ml}$ dose of SSP, platelets in an amount of 7 doses. On September, 7th 2015 Albumins $=22, \mathrm{~K}=2.8, \mathrm{Ca}=1.6$ (total). The patients was given $80 \mathrm{mEq} 7.4 \% \mathrm{KCl}, 20 \mathrm{ml} \mathrm{MgSO} 4,5$ ampoules Cagluconate ( $50 \mathrm{ml}), 100 \mathrm{ml}$ of $20 \%$ albumin. Losses through drains: abdominal $=400 \mathrm{ml}, \mathrm{T}$-drain $=200 \mathrm{ml}$. On the second postoperative day, the patient was gynecologically checked and Bromergin was introduced to therapy. The postoperative course was normal. In laboratories, on September, 16th 2015, it was observed that the pancreatic amylase $109 \mathrm{U} / \mathrm{L}$ and lipase $179 \mathrm{U} / \mathrm{L}$ declined. Hemoglobin was $96 \mathrm{~g} / \mathrm{L}$. On September, 17th 2015, the patient with clement $\mathrm{T}$ drain was relocated to the Clinic of Gynecology and Obstetrics, where the treatment was completed. With good general condition, the patient was discharged with further recommendations on treatments and checkups.

\section{Discussion}

Acute pancreatitis (AP) in pregnancy is usually related to gallstones, which makes more than $70 \%$ of all cases of pancreatitis in pregnancy. ${ }^{1}$ Hypertriglyceridemia in the third trimester of pregnancy is a more common cause of acute pancreatitis than gallstones. ${ }^{2} \mathrm{AP}$ in pregnancy can be associated with HELLP syndrome or preeclampsia, leading to high mortality of the fetus or premature birth. ${ }^{3}$ Other causes include medications containing metformin and sitagliptin. ${ }^{4}$ Diabetes mellitus type 2 increases the risk of acute pancreatitis 2.8 times. ${ }^{5}$ Due to physiological changes, pregnancy itself contributes to the development of AP. Hyperthyroidism, connective tissue diseases, infections and trauma are other rare causes of acute pancreatitis. However, the primary diseases are absent in most cases (57.89\%). ${ }^{6} \mathrm{AP}$ in pregnancy is difficult to diagnose in the first trimester compared to the third trimester. The most common clinical symptomatology are abdominal pain (89.47\%) and emesis (68.42\%). ${ }^{3}$ When assessing patients with AP these four questions should be answered:

\section{Does the patient has acute pancreatitis?}

2. If there is an acute pancreatitis, which form? The seriousness (whether it is mild or severe form of acute pancreatitis)?

\section{Is there a biliary etiology?}

\section{Which trimester of pregnancy is it?}

This last question will determine the selection of diagnostics and therapy regimen.7 Ultrasound diagnosis is safe and inexpensive, but it has a low diagnostic value for the AP. Cholangiopancreatography (MRCP) without contrast is another diagnostic method and has over 90\% sensitivity. A mild form of acute pancreatitis (MAP), as the most common, is usually treated in the first week and runs without complication. Severe acute pancreatitis (SAP) is defined by a dysfunction of the pancreas, which lasts longer than 48 hours. ${ }^{8} \mathrm{MAP}$ is mainly treated conservatively. ${ }^{1}$ The treatment consists of restoring fluid, oxygen support, analgesics, and the cessation of food intake to suppress exocrine pancreatic function, which prevents its autodigestion. ${ }^{9}$ The treatment of acute pancreatitis due to gallstones and gallbladder disease during pregnancy depends on gestational age, presence or absence of choledohal diletation, the presence of cholangitis and severity of acute pancreatitis. ${ }^{1}$ Indications for surgical treatment are: obstructive jaundice, acute cholecystitis resistant to treatment and peritonitis. ${ }^{1}$ In MAP, enteral nutrition is not necessary and fat-free diet can begin within 3-5 days. ${ }^{10}$ In SAP, enteral nutrition should be carried through nasojejunal probe. Prophylactic use of antibiotics in acute pancreatitis is controversial. ${ }^{11}$ Meta analyzes have shown that antibiotic prophylaxis does not reduce mortality nor it reduces the incidence of surgical interventions. ${ }^{11}$ Prognosis for mild forms of acute pancreatitis (MAP) is excellent without adverse effects on the fetus or the mother. In 2009, no cases of perinatal mortality have been reported in 73 patients with acute pancreatitis in pregnancy during the second and third trimester of pregnancy, and all babies were born full term. ${ }^{10}$ Despite the abovementioned, fetal risks in AP during pregnancy, including preterm delivery and intrauterine fetal death, still exist. ${ }^{1}$

\section{Conclusion}

The incidence of acute pancreatitis (AP) in pregnancy varies and ranges from 1 in 1.000 to 1 in 10.000 pregnant 
women. More than $50 \%$ of cases are diagnosed in the third trimester of pregnancy. The most common cause of AP in pregnancy is gallstones. Given the course of the disease, there is a mild and severe form of acute pancreatitis. The selection of diagnostic and treatment regimen determines the trimester of pregnancy (gestational age). Conservative treatment of mild forms of acute pancreatitis in pregnant women is the first method of treatment, especially if the fetus is not in full maturity. Conservative treatment, which replaced the earlier position on the surgical treatment, as the first method of treatment may be associated with reduced mortality compared to the previous period. Treatment of acute pancreatitis due to gallstones and gallbladder disease in pregnancy depends on gestational age, presence or absence of choledohal diletation, the presence of cholangitis and severity of acute pancreatitis. Indications for surgical treatment are: obstructive jaundice, acute cholecystitis resistant to treatment and peritonitis. In our case, given the progress of the pregnancy and fetal maturity, it was decided to perform a Caesarean section (Sectio Cesare) and surgically treat the disease (Laparatomia mediana expl., Holecystectomio,Holedochotomiom cum T-drainagae,Dilatatio papilae Vaterii).

\section{References}

1. C.S.Pitchumoni, B. Yegneswaran. Acute pancreatitis in pregnancy. World Journal of Gastroenterology 2009;15(45):5641-5646.

http://dx.doi.org/10.3748/wjg.15.5641

PMCid:PMC2789215

2. Eddy JJ, Giodeonsen MD, Song JY, Grobman WA, O'Halloran. Pancreatitis in pregnancy. Obstetrics and Ginecology 2008;112(5):1075-1081.

http://dx.doi.org/10.1097/AOG.obo13e318185a032

PMid:18978108 PMCid:PMC2833089

3. Thulasidass, Chowdhury TA. Hypertriglyceridemic pancreatitis in pregnanacy: case reports and review of the literature. JRSM Short Reports 2013;4(8):1-3.

http://dx.doi.org/10.1177/2042533313481211

PMid:24040494 PMCid:PMC3767063

4. Matveyenko VA, Dry S, Cox HI, et al. Beneficial endocrine but adverse exocrine effects of sitagliptin in the human islet amyloid polypeptide transgenic rat model of type 2 diabetes: interaction with metformin. Diabetes 2009;58(7):16041615.

http://dx.doi.org/10.2337/dbo9-0058

PMid:19403868 PMCid:PMC2699878

5. Noel AR, Braun KD, Patterson ER, Bloomgren LG. Incrased risk of acute pancreatitis and biliary disease observed in patients with type 2 diabetes : a retrospective cohort study. Diabetes Care 2009;32(5):834-838.

http://dx.doi.org/10.2337/dco8-1755

PMid:19208917 PMCid:PMC2671118

6. L. Zhang. Y. Huang, L. Yan, X.Ran. Thirty eight cases of acute pancreatitis in pregnancy: a 6-year single center retrospective analysis. Journal of Houazhong University of Science and Tehnology 2013;33(3):361-367.

http://dx.doi.org/10.1007/s11596-013-1125-8

PMid:23771661

7. Mitura K, Romanczuk M. Ruptured ectopic pregnancy mimicking acute pancreatitis. Ginekologia Polska 2009;80(5):383-385. PMid:19548460

8. Banks AP, Bollen LT; Dervenis C, et al. Classification of acute pancreatitis-2012: revision of the Atlanta classification and definitions by international consensus. Gut 2013;62(1):102111

http://dx.doi.org/10.1136/gutjnl-2012-302779

PMid:23100216

9. Stimec T, Stimec D. Acute pancreatitis During Pregnanacy 2012.

10. Tang SJ, Rodriguez-Frias E, Singh S, et al. Acute pancreatitis during pregnanacy. Clinical Gastroenterology and Hepatology 2010;8(1):85-90.

http://dx.doi.org/10.1016/j.cgh.2009.08.035

PMid:19747985

11. Jafri NS, Mahid SS, Idstein CA, Hornung CA, Galandiuk $\mathrm{S}$. Antibiotic prophylaxis is not protective in severe acute pancreatitis: a systematic review and meta-analisis. The American Journal of Surgery 2009;197(6):806-813. http://dx.doi.org/10.1016/j.amjsurg.2008.08.016 PMid:19217608

\section{Akutni pankreatitis u trudnoći}

\section{SAŽETAK}

Uvod: Acute Akutni pankreatitis (AP) u trudnoći se najčešće dijagnostikuje u trećem trimestru. Najčešći etiološki faktori su kolestaza i koledokoltijaza. Najteža posljedica je letalni ishod po majku i dijete. Letalni ishod je u velikoj mjeri smanjen upotrebom: savremene dijagnostike (ultrazvuk, magnetna rezonanca, endoskopija, laparoskopija), ranim započinjanjem terapije i multidisciplinarnim pristupom rješavanju problema. 